\title{
Sustainable mangrove rehabilitation: Lessons and insights from community-based management in the Philippines and Myanmar
}

Leni D. Camacho ${ }^{a *}$, Dixon T. Gevaña a, Lorena L. Sabino a, Clarissa D. Ruzol a, Josephine E. Garcia a, April Charmaine D. Camacho a , Thaung Naing Oo ${ }^{b}$, Aye Chan Maung ${ }^{b}$, K. G. Saxena ${ }^{c}$, Luohui Liang ${ }^{d}$, Evonne Yiu ${ }^{\mathrm{d}}$, and Kazuhiko Takeuchi ${ }^{\mathrm{d}}$

a University of the Philippines Los Baños, Philippines

$b$ Forest Research Institute, Myanmar

Jawaharlal Nehru University, India

d United Nations University Institute for the Advanced Study of Sustainability, Japan

* Corresponding author. Email: ldcamacho@up.edu.ph

\section{ABSTRACT}

This study generally aims to synthesize the best practices and challenges in mangrove rehabilitation in the Philippines, Myanmar, Japan, China and India. It employed an in-depth review of secondary information such as policy documents and project reports, and participatory research activities with various mangrove stakeholders such as key informant interview and focus group discussion. Lessons and strategies obtained were used to develop a mangrove rehabilitation framework or guideline. The guideline was tested for suitability through case studies in the Philippines and Myanmar. It was concluded that mangrove rehabilitation will succeed if 1 ) it is built around an integrated and ecosystem-based approach that takes into account feedback between rehabilitation and other economic activities; 2) its scope is beyond mere planting; 3 ) local people are involved in planning and monitoring in addition to implementation; 4) all stakeholders are informed of their roles and responsibilities; and 5) species selection is based on ecological and silvicultural knowledge in conjunction with the needs and priorities identified by stakeholders.

\section{INTRODUCTION}

Mangroves provide a range of ecosystem services. These largely include the provision of timber, fuel wood, medicines, natural dyes, honey, and marine food. They also help in regulating floods, erosion and saltwater intrusion; and protect coastal communities against the harsh impacts of storms and tsunamis. Further, there are several aesthetic and cultural services that mangroves provide, including those related to tourism, education, and local indigenous knowledge and traditions. Mangroves are confined largely to the tropics and sub-tropics. Among the continents, Asia has the most extensive mangrove forest cover, but with the most serious deforestation rates (Food and Agricultural Organization of the United Nations [FAO], 2015). Mangroves, particularly in Southeast Asia, are globally distinguished for their high biodiversity (Tomlinson, 1986; Giesen \& Wulffraat, 1998). Mangrove cover has been reduced from $6,025,000$ ha in 2010 to $5,329,000$ ha in 2015 (FAO, 2015). Many mangrove stands are on the brink of complete collapse after being converted to

\section{KEYWORDS}

Community, Mangrove, Participatory, Sustainable rehabilitation

\section{DOI}

https://doi.org/10.30852/sb.2020.946

\section{DATES}

Received: 30 August 2019

Published (online): 7 April 2020

Published (PDF): 3 September 2020

This work is licensed under a Creative Commons Attribution-NonCommercial 4.0 International License.

\section{HIGHLIGHTS}

" Science-based approach in coastal rehabilitation is being promoted to solve worsening coastal environmental problems.

» Community-based forest management approach encourages participation, strong collaboration and commitment of local communities in collaboration with research institutions, government and nongovernment institutions.

» Science-based rehabilitation guidelines should be communicated well to local communities.

» Key facilitating factors for successful mangrove rehabilitation are clear policies, secured rights, and good governance. 


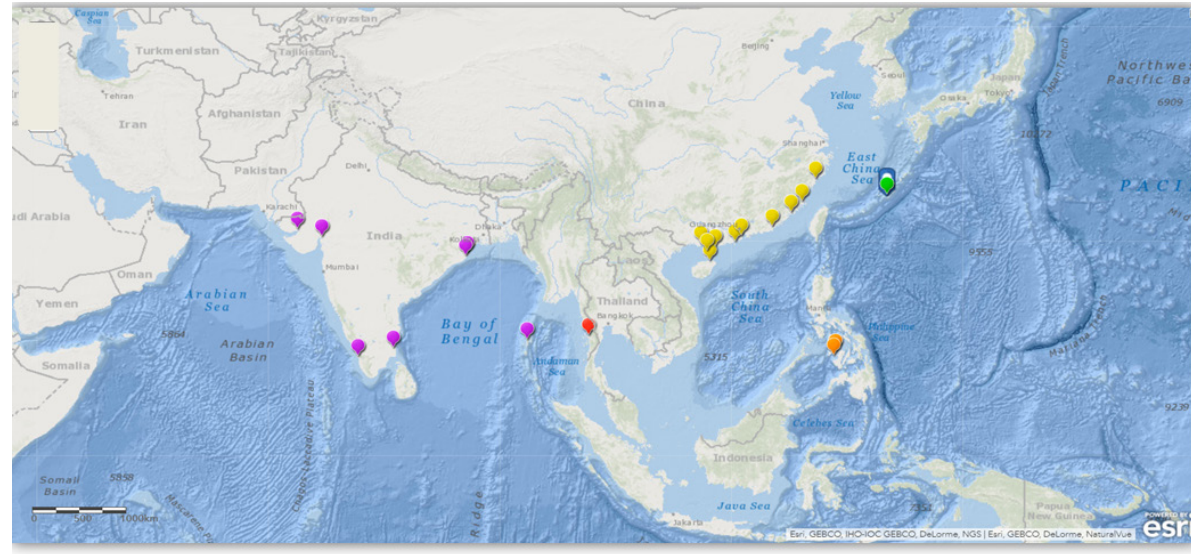

Legend: India Myanmar China Japan Philippines

aquaculture ponds, agricultural farms, oil palm and settlement areas (Kathiresan \& Bingham, 2001; Gevaña, Pulhin, \& Tapia, 2019). Low awareness of ecological and economic values of mangroves also led to their neglect in national forest conservation and biodiversity protection plans (Snedaker, 1984).

Over the past two decades, mangrove conservation and rehabilitation have gained interests with the increasing recognition of their role to minimize the impacts of tsunami and storm surge (Garcia, Malabrigo \& Gevaña, 2014; Gevaña, Camacho, \& Pulhin, 2018). Further, mangrove plantation development was also driven by the increasing demand for fuelwood, poles, charcoal and woodchips, and more importantly, because of their ecological ecosystem functions (Aksornkoae \& Kato, 2011). However, numerous planting efforts implemented were unsuccessful due to the lack of science-based approach guidelines (Primavera and Esteban (2008); LópezPortillo et al., 2017).

Given the challenges in mangrove conservation, a collaborative research study was undertaken to synthesize the best practices and challenges in mangrove rehabilitation in the Philippines, Myanmar, Japan, China and India. Further, this study endeavoured to develop mangrove rehabilitation frameworks/guidelines by distilling the best practices and lessons learned from the secondary information, participatory assessment of the outcomes of rehabilitation treatments in field in selected areas and collaboration of multi-country team of researchers, as supported by the Asia Pacific Network for Global Change Research (APN).

\section{METHODOLOGY}

To achieve the study objectives, participatory research methods were undertaken. These included:

» review of secondary data (e.g. policy documents, project reports and scientific publications) in terms of the different elements of rehabilitation treatments; ecological, economic and social
FIGURE 1. Location map of study areas in Asia. Source: ArcGIS Online. costs and benefits; challenges and opportunities; and implementation arrangements described covering all mangrove areas in the Philippines, Myanmar, Japan, China and India (Figure 1); and

» key informant interviews (KII) with various mangrove stakeholders (e.g. government agencies, non-government organizations, and local community organizations).

Results of the review and participatory research activities were synthesized to develop a mangrove rehabilitation framework, or guidelines. To check the guideline suitability, case analyses were undertaken in three communities in the Philippines, and one in Myanmar. This involved the conduct of focus group discussions with selected local community members implementing mangrove rehabilitation projects.

\subsection{Study sites}

The study covered mangrove rehabilitation efforts in the Philippines; Myanmar, Japan, China and India (Figure 1). The Philippines has estimated mangrove forests of about 356,000 ha, with a recent decadal deforestation rate of $0.5 \%$ (Gevaña, Camacho, \& Pulhin, 2018). In Myanmar, mangroves span 502,911 ha. In India, Sundarbans are well-known as one of the most extensive contiguous mangrove forests in the world. India has 4,921 sq. $\mathrm{km}$ of mangroves, contributing $3.2 \%$ of the global estimate. Five provinces viz., Guangdong Province, Guangxi Autonomous Region, Hainan Province, Fujian Province and Zhejiang Province cover 57.3\%, 25.5\%, $13.7 \%, 3.4 \%$ and $0.1 \%$ of the total mangrove area $(17,800$ ha) of China, respectively. In Japan, mangroves are found chiefly in the southernmost prefectures of Kagoshima and Okinawa, with its northern limit located in Kiore. They cover about 553 ha.

\subsection{Study components and methods}

The study aimed to identify mangrove rehabilitation practices, challenges, and lessons learned among the 
collaborating countries. In summary, the research team accomplished the following activities:

" A literature review of past reports on mangrove rehabilitation (from the year 2000 onwards) and state-of-the-art knowledge of mangrove ecology was examined.

"A list of criteria summarizing the success and challenges of rehabilitation was developed, namely: 1) site; 2) duration and budget; 3) planting design (including species composition); 4) survival rate; 5) stakeholder participation; 6) provision of socio-economic benefits; and 7) success and constraining factors.

» In-depth on-site case studies in the Philippines and Myanmar describing suitability of the proposed guidelines/comprehensive framework through key informant interviews (KII) and focus group discussions (FGDs).
» Policy consultations with relevant government, non-government, academic and research institutions were held through KII and FDGs. These were aimed at eliciting: 1) key mangrove rehabilitation policies and programmes and their congruence with sustainability; 2) effectiveness of policy implementation; 3 ) perceived issues and challenges in policy implementation; and 4) recommendations to improve policies.

\section{RESULTS AND DISCUSSION}

\subsection{Mangrove rehabilitation best practices, challenges and lessons learned}

The literature review supplemented by field observations in selected locations suggested that empowerment of local communities by legitimizing their resource

\begin{tabular}{|c|c|c|c|c|}
\hline Country & $\begin{array}{l}\text { Reasons for mangrove } \\
\text { losses }\end{array}$ & Best practices & Issues and challenges & Lessons learned \\
\hline Philippines & $\begin{array}{l}\text { - Conversion to } \\
\text { aquaculture ponds, rice } \\
\text { paddies and reclamation } \\
\text { for settlement and } \\
\text { industrial development } \\
\text { - Typhoons/storms }\end{array}$ & $\begin{array}{l}\text { - Adoption of community- } \\
\text { based forest management } \\
\text { (Executive Order No. 263, } \\
\text { 1995) that has spurred } \\
\text { collective efforts to } \\
\text { rehabilitate other degraded } \\
\text { coastal environments }\end{array}$ & $\begin{array}{l}\text { - Poor survival in plantations } \\
\text { due to wrong choice of species } \\
\text { for planting } \\
\text { - The CBFM participants in } \\
\text { mangrove areas cannot avail } \\
\text { the incentives compared with } \\
\text { the CBFM participants in the } \\
\text { upland areas such as security } \\
\text { of tenure and exemption from } \\
\text { forest charges for harvesting }\end{array}$ & $\begin{array}{l}\text { - Need for harmonised } \\
\text { mangrove policies } \\
\text { and institutions to } \\
\text { help promote effective } \\
\text { sustainable management } \\
\text { and rehabilitation } \\
\text { - Science-based process } \\
\text { is a prerequisite for } \\
\text { rehabilitation }\end{array}$ \\
\hline Myanmar & $\begin{array}{l}\text { - Extraction of fuelwood/ } \\
\text { timber } \\
\text { - Mangrove conversion } \\
\text { into shrimp ponds, } \\
\text { settlements and rice } \\
\text { paddies } \\
\text { - Large scale fish and } \\
\text { prawn farming }\end{array}$ & $\begin{array}{l}\text { - Adoption of mangrove- } \\
\text { based agroforestry practices, } \\
\text { community-based mangrove } \\
\text { management and ecological } \\
\text { mangrove restoration }\end{array}$ & $\begin{array}{l}\text { - Limited studies that assess } \\
\text { the causes of degradation and } \\
\text { insufficient communication } \\
\text { of results } \\
\text { - Policy gaps on requiring } \\
\text { feasibility assessment, } \\
\text { monitoring and enforcement } \\
\text { through multi-disciplinary } \\
\text { approaches }\end{array}$ & $\begin{array}{l}\text { - Need for integrated } \\
\text { approach to mangrove } \\
\text { rehabilitation, including: } \\
\text { - knowledge-based } \\
\text { planting methods, } \\
\text { - social mobilization, } \\
\text { - livelihood support } \\
\text { - policies on reaching } \\
\text { planting }\end{array}$ \\
\hline India & $\begin{array}{l}\text { - Conversion to urban } \\
\text { zones and shrimp farms } \\
\text { - Overharvesting } \\
\text { - Storms and urban } \\
\text { pollution }\end{array}$ & $\begin{array}{l}\text { - Legal and regulatory } \\
\text { institutions were set up for } \\
\text { the protection of mangroves } \\
\text { - Integration of apiculture } \\
\text { with rehabilitation for local } \\
\text { income }\end{array}$ & $\begin{array}{l}\text { - Inadequate labour resources, } \\
\text { lack of facilities, and } \\
\text { inappropriate use of financial } \\
\text { resources } \\
\text { - Both plantations and natural } \\
\text { forests in deltaic regions } \\
\text { suffer massive losses due to } \\
\text { erosion }\end{array}$ & $\begin{array}{l}\text { - Need for long term- } \\
\text { participatory-adaptive } \\
\text { restoration programmes }\end{array}$ \\
\hline China & $\begin{array}{l}\text { - Conversion to } \\
\text { agriculture/aquaculture } \\
\text { - Reclamation for urban } \\
\text { development } \\
\text { - Overfishing and } \\
\text { introduction of invasive } \\
\text { species }\end{array}$ & $\begin{array}{l}\text { - Selective cutting and gap } \\
\text { planting of Sonneratia } \\
\text { apetala in secondary forests } \\
\text { - Ecological aquaculture } \\
\text { combining mangrove } \\
\text { rehabilitation with shrimp } \\
\text { farming }\end{array}$ & $\begin{array}{l}\text { - Reforestation on bare } \\
\text { beaches and integration with } \\
\text { human-made fish reefs are } \\
\text { very costly to implement } \\
\text { - Survival rate of mangrove } \\
\text { seedlings remains quite low }\end{array}$ & $\begin{array}{l}\text { - Strengthen protection } \\
\text { of mangrove nature } \\
\text { reserves, rehabilitation } \\
\text { of degraded mangroves, } \\
\text { and provide more } \\
\text { support for research and } \\
\text { rehabilitation work }\end{array}$ \\
\hline Japan & $\begin{array}{l}\text { - Cutting for firewood, } \\
\text { construction material, } \\
\text { dyeing and antiseptic } \\
\text { agents } \\
\text { - Reclamation for urban } \\
\text { and industrial areas }\end{array}$ & $\begin{array}{l}\text { - No aquaculture farms in } \\
\text { mangroves area } \\
\text { - Cutting and destroying } \\
\text { mangroves are strictly } \\
\text { restricted } \\
\text { - Tourism is a more beneficial } \\
\text { industry than aquaculture }\end{array}$ & $\begin{array}{l}\text { - Land-based problems such } \\
\text { as red-soil runoff due to } \\
\text { unsustainable agriculture } \\
\text { practices and garbage } \\
\text { pollution }\end{array}$ & $\begin{array}{l}\text { - Mangroves are well- } \\
\text { conserved in Japan } \\
\text { for their ecological, } \\
\text { educational and touristic } \\
\text { values }\end{array}$ \\
\hline
\end{tabular}

TABLE 1. Best practices, challenges and lessons learned regarding mangrove rehabilitation from participating countries. 


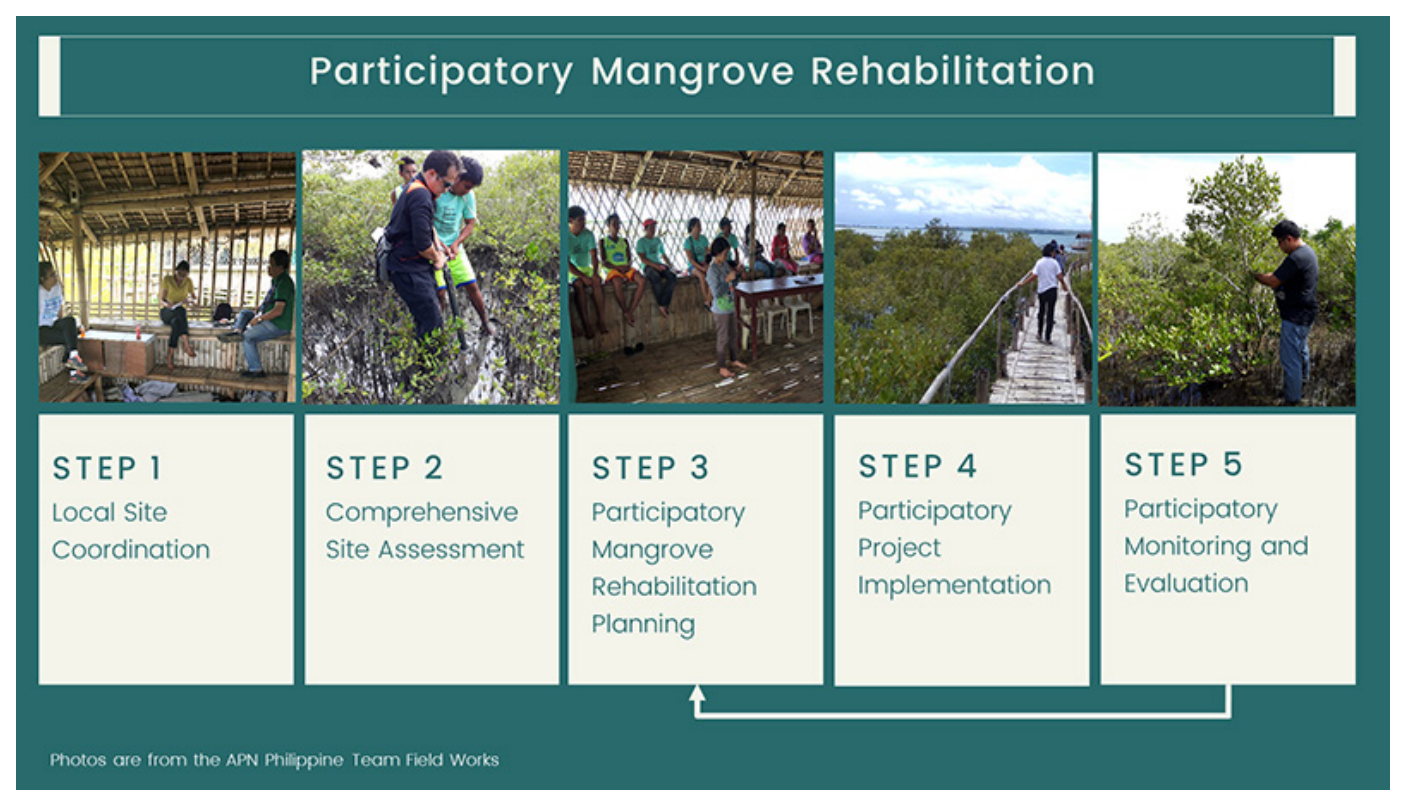

FIGURE 2. Participatory Mangrove Rehabilitation Framework.

use rights as well as management responsibilities was the key factor driving successful mangrove restoration in the Philippines and Myanmar. Furthermore, local income from non-timber forest products (in India), ecotourism (in Japan), and shrimp farming (in China) are guaranteed if healthy mangrove forests are wellkept. In all countries, the feedbacks between mangrove restoration, other land uses and non-land economic activities were considered crucial for conserving biodiversity, mitigating climate change, increasing resilience to climate change, and sustainable socioeconomic development. Poor survival rates of planted mangroves were observed to be the result of: 1) poor planning; 2 ) limited understanding of the site's ecology; 3) poor programme management/governance/policy concerns; 4) tenure insecurity; 5) occurrence of natural disasters; 6) poor monitoring; and (7) lack of timely corrective measures (Table 1).

\subsection{Guidelines and comprehensive framework for sus- tainable mangrove rehabilitation}

Using the information from lessons learned on past and current efforts in mangrove rehabilitation (Table 1), a comprehensive framework for pursuing sustainable community-based mangrove rehabilitation was developed. This framework emphasizes that rehabilitation is not merely a process of planting of trees, but a holistic effort to address broader environmental, economic and social imperatives across spatial and temporal scales (Pulhin, Gevaña, \& Pulhin, 2017). It involves several steps, as also reflected in the mangrove rehabilitation manual developed by Primavera et al. (2012) (Figure 2).

\section{2.a Local site coordination.}

Forest rehabilitation should be properly coordinated with relevant stakeholders. Ensuring transparent, just and sound stakeholder engagement is at the heart of all successful rehabilitation projects. Rehabilitation must rest on a shared vision and all stakeholders should have a clear understanding of their roles, responsibilities and benefits. This sets the foundation for ensuring accountability.

\section{2.b Comprehensive site assessment.}

Comprehensive site assessment should be undertaken by an interdisciplinary team of researchers/experts together with local people. Involvement of local people in field data collection (e.g. measuring trees, assisting in social surveys and ground validation of land uses and maps) inculcates a sense of ownership and induces efforts towards voluntary replication and indigenous innovations. Comprehensive site assessment has two major components:

» Biophysical characterization. Vegetation analysis can be done through rapid appraisal or rigorous assessment following a statistically efficient sampling design. It should capture the historical changes in land-use systems and landscape structure and function. The assessment should cover topography, hydrology, sedimentation, contamination, climate and ecosystem structure and processes. Participatory resource mapping and key informant interviews can supplement/ complement the scientific data.

» Socioeconomic characterization. Participatory Rural Appraisal (PRA) is an effective tool of capturing the level of awareness of the value of mangroves, local needs and priorities. Demographic (population, gender distribution, ethnicity, etc.), socioeconomic (income and livelihood), and cultural profiles (traditional use and management of 
mangroves) and existing institutional arrangements in managing mangroves such as property rights and stewardship arrangements must be analyzed for improved mangrove resource utilization and management practices.

\section{2.c Participatory mangrove rehabilitation planning.}

Rehabilitation planning starts with a Problem Tree Analysis. A good understanding of the problem root causes is critical to designing appropriate rehabilitation strategies. Results of the comprehensive site assessment provide insights about the key site-specific management issues. Visioning exercise, which aims to solicit a standard and ideal vision for the mangrove forest, follows the problem analysis. Such a unified vision is further interpreted into long term goals and achievable objectives over the short term in project mode operations. Stakeholders then proceed with strategic planning exercises. The following are the major components of the technical rehabilitation guidelines:

"Correct site selection. Mangrove planting should only be done within the middle to upper intertidal zones of the coastal area where mangroves naturally grow and thrive (Primavera et al., 2012). Moreover:

> Original mangrove sites (including those that are abandoned fishponds after conversion) should be the target of rehabilitation and not habitats such as seagrass beds.

> Mangrove sites vary in sizes from tiny strip to several thousand hectares. Careful planning is needed taking into account the operational constraints of time, budget and human resources.

> Correct information about the site's ecology and hydrology is vital in designing rehabilitation programme. Planting on the wrong site, at the wrong time, with the wrong species leads to failures. In summary: a) get the hydrology right; b) do not start by planting mangroves: first, find out why mangroves are not there; $c$ ) see if the reason for mangrove absence can be corrected; if not choose another site; d) use a reference site to identify the conditions suitable for mangroves in the project area; e) for the reference site, be clear about its topography before considering another area; and f) evaluate costs and benefits early in project planning to maximize cost-effectiveness.

» Nursery management. Size, cost and location of nursery depend on the amount of planting materials to be produced to complete the rehabilitation target. Nursery should be established in a strategically located area that is near the seed or wildling source, sheltered from strong waves and close to plantation sites. Tending of seedlings largely includes watering, cleaning, and hardening-off to ensure vigour. Seedling transport may be needed if planting site is far.

»Outplanting. This generally involves: a) selection of appropriate species for planting; b) configuration of species in mixed planting and spacing (number of seedlings per unit area); c) planting schedule taking in account tides; and d) selection of planting techniques.

» Site maintenance. Key activities include removal of algae and barnacles on seedlings, establishment/ maintenance of wave barriers and gap-filling.

» Field monitoring. Regular monitoring is essential to check if rehabilitation objectives are met. Ocular inspections over extensive areas and census of survivors and their height, main stem and canopy growth in selected areas enable cost-effective monitoring and corrective actions.

\section{2.d Participatory project implementation}

» Forging agreements with partner governments and academic institutions. This involves several meetings with key local government officials, NGOs and academic institutions to convey concerns for pursuing rehabilitation and clarification of property rights and roles that the community will play in rehabilitation. Eventually, an agreement (e.g. Memorandum of Agreement or resolution) with important stakeholders (particularly local community) could be sought to ensure provisions of sustained support or commitment to rehabilitation.

" Community organization (CO) and strengthening communications. COs should immerse themselves in the local partner community to gain an in-depth understanding of local needs, strengths and opportunities. Once COs have a thorough feel for these aspects, they can conduct capacity building activities such as People's Organization (PO) formation, leadership training, and livelihood training. One of the major goals of these activities is to increase local awareness/knowledge about the importance of mangrove conservation, and how such endeavours will uplift their general well-being. Cross-site visits, hands-on training on mangrove ecology, nursery management, and site monitoring can be made available to the local community to further equip them with necessary technical knowledge. 
» Community mobilization. The local community should be mobilized in conducting their project planning, implementation, and monitoring and evaluation. In some cases, organized communities are tapped as partners in government mangrove planting projects, thus providing additional income source.

" Mainstreaming rehabilitation strategies.Memoranda, partnerships and other forms of agreements on mangrove rehabilitation should be further elevated into local government resolutions or ordinances to incorporate rehabilitation in community-led local development plans.

\section{2.e Participatory monitoring and evaluation.}

Monitoring project progress, vis-à-vis satisfaction of objectives and targets by the local community and partner institutions, is vital to elicit measures to keep the project on track. Mutual sharing of information is an effective way of promoting transparency and commitments.

\subsection{Suitability of the proposed mangrove rehabilitation guidelines: Case studies in the Philippines and Myanmar}

In the Philippines, three case studies were completed to assess the applicability of the mangrove rehabilitation guidelines. These included: 1) Katunggan Ecopark at Leganes, Iloilo (a joint scheme of local community,

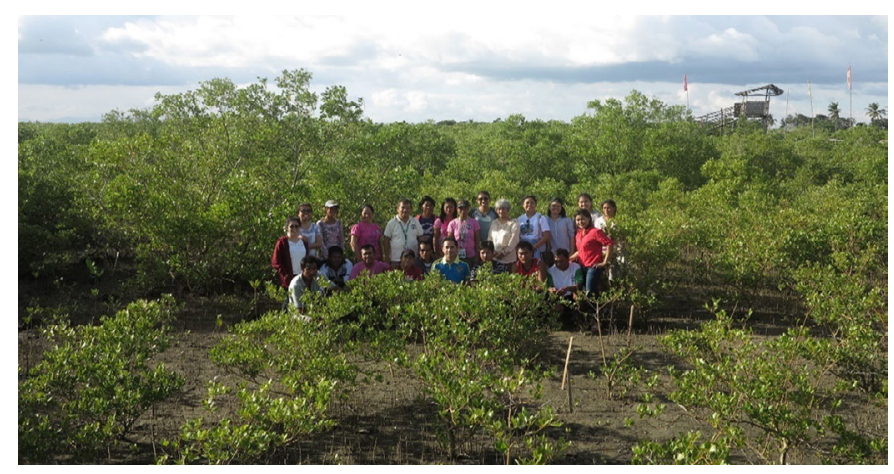

FIGURE 3. The Philippine Research Team with stakeholders at Katunggan Ecopark at Leganes, Iloilo.

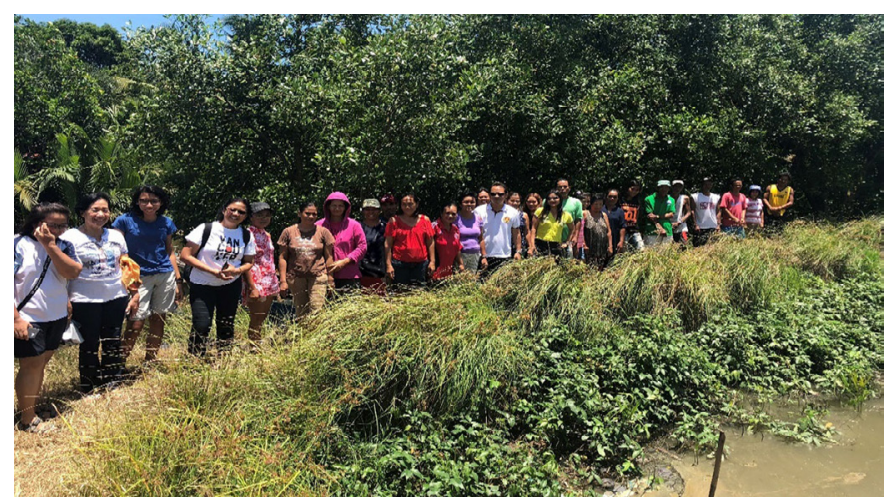

FIGURE 4. The Philippine Research Team with stakeholders at Barotac Nuevo, Iloilo. local government unit (LGU) and a Non-Governmental Organization viz., the Zoological Society of London (ZSL); 2) Taklong Island Marine Reserve in Guimaras Province (Scheme: local community in partnership with the Department of Environment and Natural Resources, or DENR); and 3) Jalaud Mangrove Rehabilitation in Barotac Nuevo, Iloilo (Scheme: local community in partnership with the Iloilo State College of Fisheries).

As a background, rehabilitation project in Leganes in Iloilo started in 2009. It began with the initiative of the ZSL. In Taklong Island Marine Reserve (TINMAR) rehabilitation was led by the DENR in response to an oil spill disaster in 2006 and as a component of the National Greening Programme (NGP) in 2011. Lastly, rehabilitation efforts in typhoon-damaged fishponds of Barotac, Nuevo, Iloilo started in 2013 as part of the national aquasilviculture programme of the Bureau of Fisheries and Aquatic Resources (DA-BFAR). Photos of these sites during field data collection of the Research Team are presented in Figures 3 and 4 .

In Myanmar, the Myeik Forest Department organized the Taw HtwinGyi Community Forestry in 2016 to initiate community-based mangrove rehabilitation efforts in Myeik Township, Tanintharyi Region.

Results of the case study showed that before the establishment of Community Forestry, mangroves were cleared for urban expansion and agriculture. The lack of community ownership or tenure rights over mangrove areas was noted as the major challenge in promoting mangrove conservation. Mangrove rehabilitation was mentioned as an offshoot of the community forestry programme in partnership with local people, Myeik Forest Department officials, and NGOs namely, Myanmar Green Network (MGN) and Flora and Fauna International (FFI).

Table 2 summarizes the key activities and practices in view of the proposed mangrove rehabilitation framework. Results showed that rehabilitation was unlikely to succeed if people were excluded from the planning and monitoring process or, alternatively, were involved solely in the capacity as implementers of top-down decisions, an approach which was widespread until recently. Thus, wholehearted and committed participation of local communities is a prerequisite for successful rehabilitation, and this participation can be secured by actively involving people in the planning and monitoring process. It was also evident that mangrove species differed with respect to their adaptation to salinity and flooding and had a narrow range of tolerance in the establishment phase. There is an urgent need for enhancing silvicultural knowledge of mangroves, an aspect neglected in the past, to increase the effectiveness and efficiency of rehabilitation. These conclusions are 


\begin{tabular}{|c|c|c|c|c|c|c|}
\hline \multicolumn{2}{|c|}{ 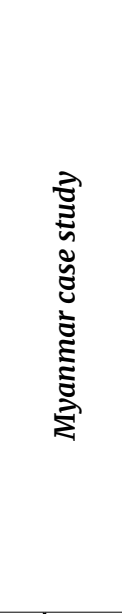 } & 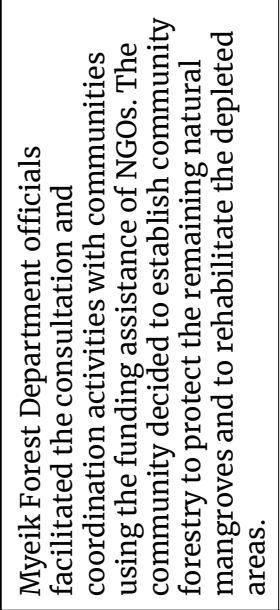 & 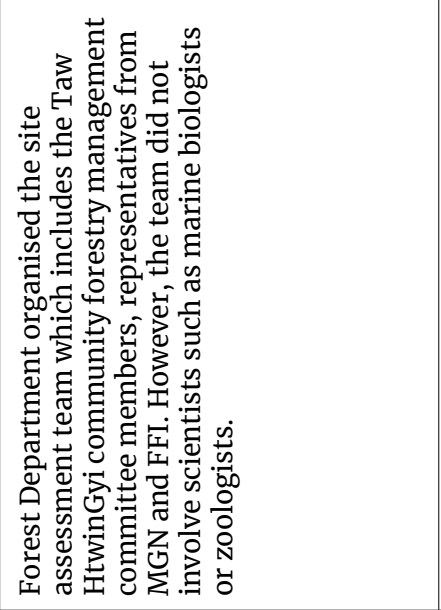 & 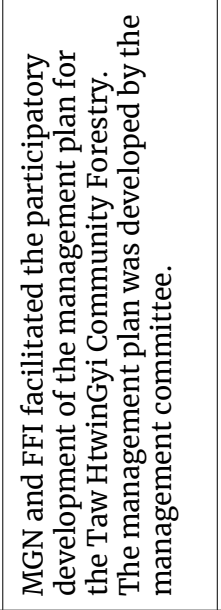 & 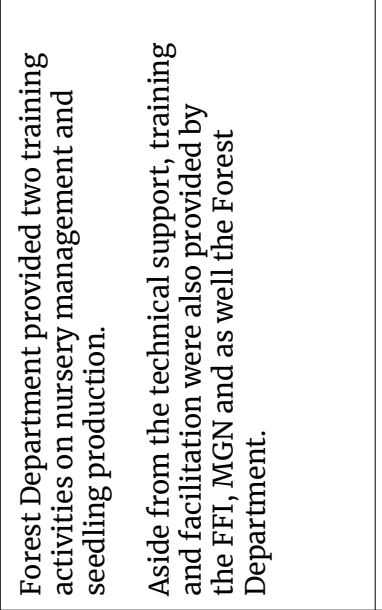 & 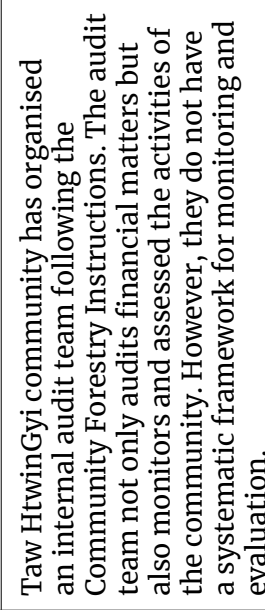 \\
\hline \multirow{3}{*}{ 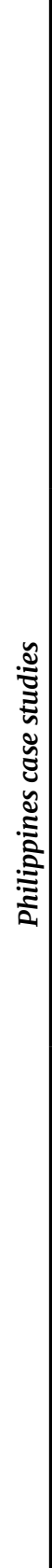 } & 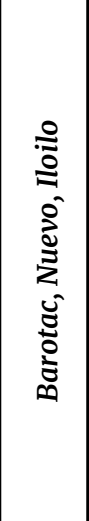 & 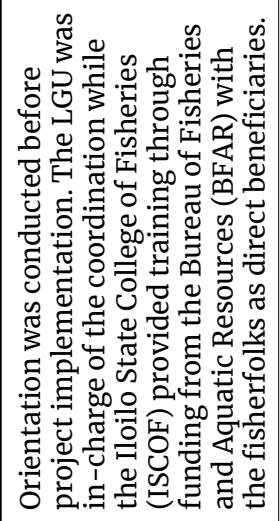 & 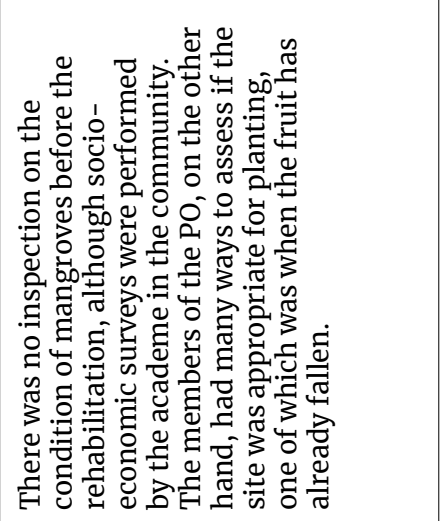 & 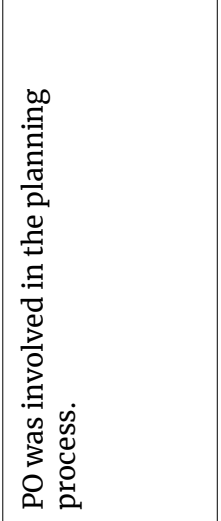 & 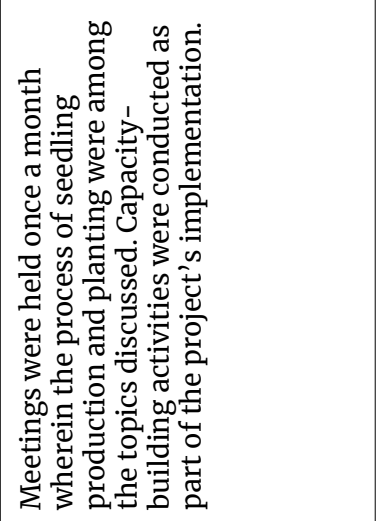 & 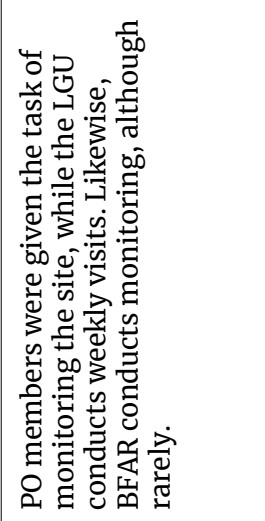 \\
\hline & 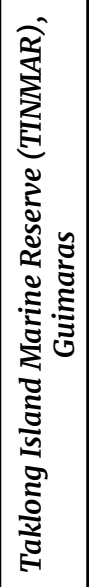 & 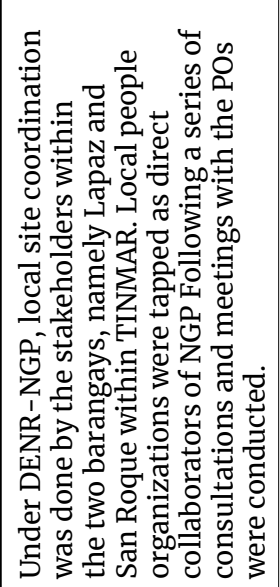 & 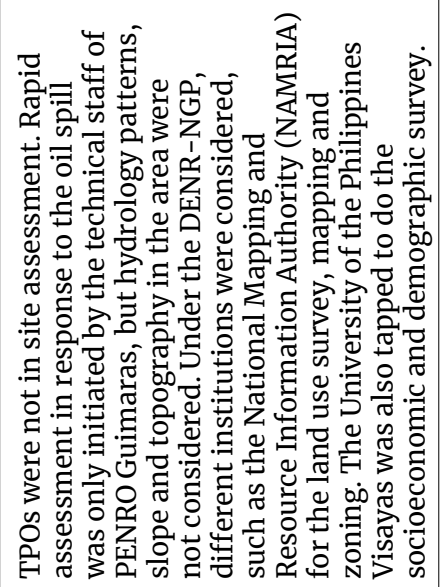 & 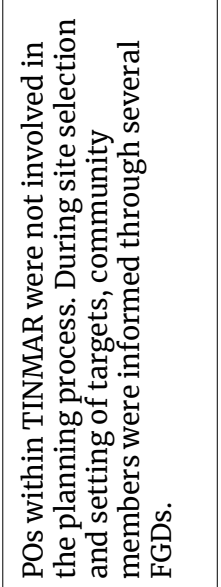 & 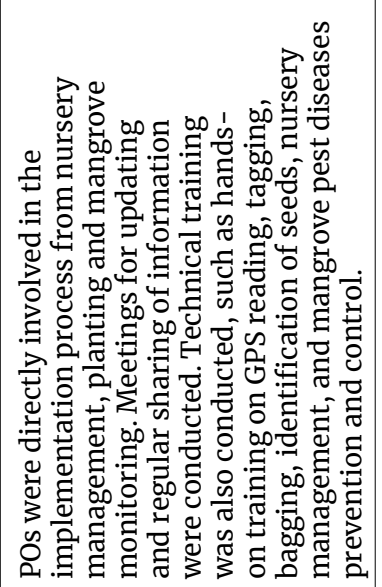 & 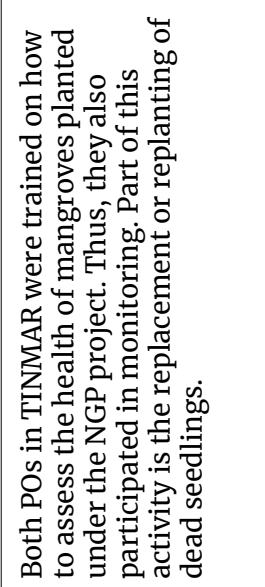 \\
\hline & 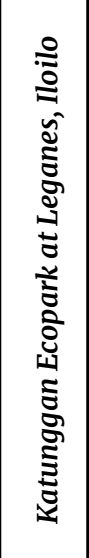 & 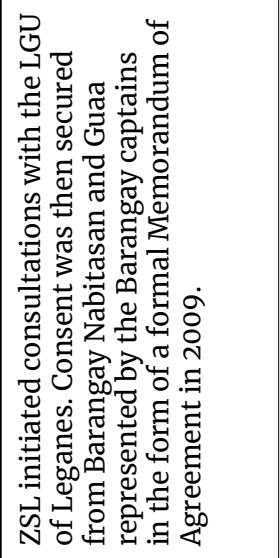 & 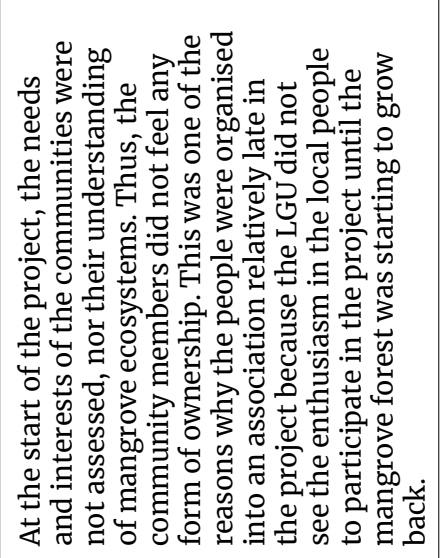 & 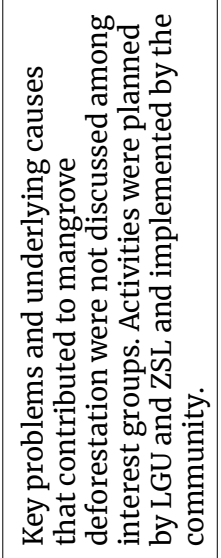 & 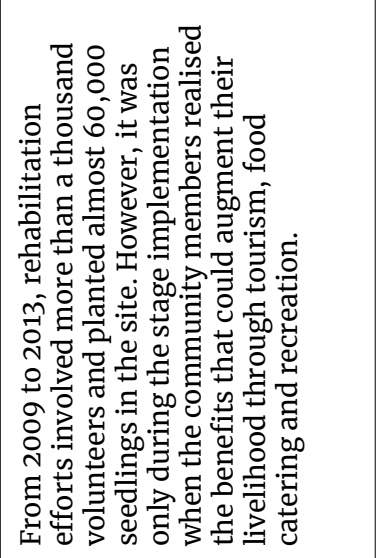 & 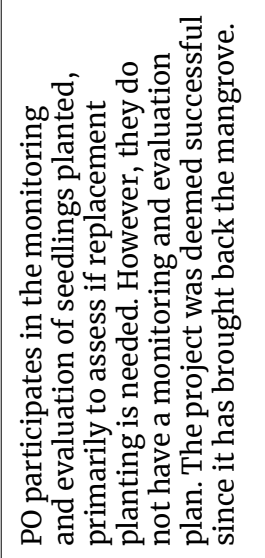 \\
\hline & 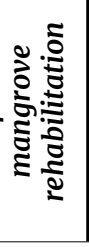 & 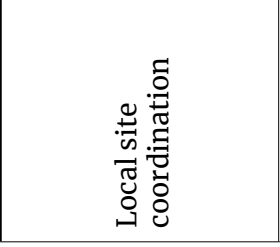 & 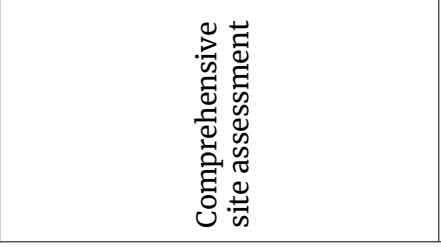 & 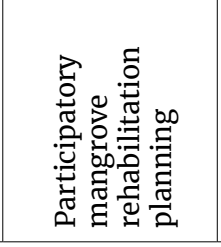 & 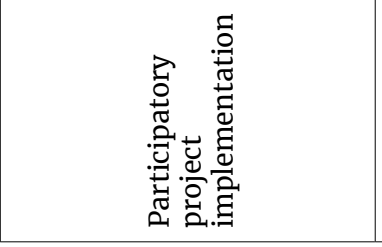 & 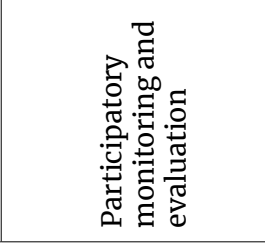 \\
\hline
\end{tabular}


corroborated by the reports of Walters (2004), Samson and Rollon (2008), Primavera and Esteban (2008), and Thompson, Clubbe, Primavera, Curnick, and Koldewey (2014).

\section{CONCLUSION}

Mangrove rehabilitation should be understood as an inherently slow, expensive, complex and uncertain process. Rehabilitation demands: 1 ) integrated and ecosystem-based approaches taking into account feedbacks between rehabilitation, other land/aquatic resource uses, and non-land/ocean-based economic activities; 2) widening the scope of rehabilitation beyond merely planting; 3) participation of local people in planning and monitoring in addition to implementation; 4) clarity in the roles and responsibilities of different stakeholders; and 5) selection of plantation species based on ecological and silvicultural knowledge in conjunction with the needs and priorities identified by the stakeholders. In summary, ensuring sustainable and effective mangrove rehabilitation, active collaboration among government, non-government organizations, funding agencies, and research institutions and, most importantly, by local communities is vital.

\section{ACKNOWLEDGEMENT}

This research was supported by APN. The team would like to thank all who contributed their invaluable time, generous assistance and constructive advice to this project.

\section{REFERENCES}

Aksornkoae, S., \& Kato, S. (2011). Mangroves for the people and environmental conservation in Asia. Bulletin of the Society of Sea Water Science, Japan., 65 (1), 3-9.

Food and Agriculture Organization of the United Nations. (2015). Global forest resources assessment 2015: Desk reference. Rome: Food and Agriculture Organization of the United Nations.

Garcia, K., Malabrigo, P., \& Gevaña, D. (2014). Philippines' mangrove ecosystem: status, threats and conservation. In Mangrove Ecosystems of Asia (pp. 81-94). New York: Springer.

Gevaña, D., Camacho, L., \& Pulhin, J. (2018). Conserving mangroves for their blue carbon: Insights and prospects for community-based mangrove management in Southeast Asia. In Makowski C., Finkl C. (Eds.), Threats to Mangrove Forests (pp. 579-588). Springer Nature.

Gevaña, D., Pulhin, J., \&Tapia, M. (2019). Fostering climate change mitigation through a community-based approach: Carbon stock potential of community-managed mangroves in the Philippines. In Krishnamurthy, Jonathan, Srinivasalu, Glaeser (Eds.), Coastal Management: Global Challenges and Innovations (pp. 271-282). Elsevier.

Giesen, W., \& Wulffraat, S. (1998). Indonesian mangroves, part 1: Plant diversity and vegetation. Tropical Biodiversity, 5(2), 11-23.

Kathiresan, K., \& Bingham, B. (2001). Biology of mangroves and mangrove ecosystems. Advances in Marine Biology, 40, 81-251.

López-Portillo, J., Lewis III, R., Saenger, P., Rovai, A., Koedman, N., Dahdouh-Guesbas, F., ... \& RiveraMonroy, V. (2017). Mangrove forest restoration and rehabilitation. In VH Rivera-Monroy, S Yip Lee, E Kristensen \& RR Twilley (eds). Mangrove ecosystems: a global biogeographic perspective. (pp. 301- 345). Springer, Switzerland.

Primavera, J., \& Esteban, J. (2008). A review of mangrove rehabilitation in the Philippines: Successes, failures and future prospects. Wetlands Ecology and Management, 16 (3), 173-253.

Primavera, J., Savaris, J., Bajoyo, B., Coching, J., Curnick, D., Golbeque, R., ... \& Koldewey, H. (2012). Manual on community-based mangrove rehabilitation. Mangrove Manual Series, 1. London: Zoological Society of London.

Pulhin, J., Gevaña, D., \& Pulhin, F. (2017). Communitybased mangrove management in the Philippines: Experience and challenges in the context of changing climate. In R. DasGupta, \& R. Shaw (Eds.), Participatory Mangrove Management in a Changing Climate (pp. 247-262). Springer, Tokyo.

Samson, M., \& Rollon, R. (2008). Growth performance of planted mangroves in the Philippines: Revisiting forest management strategies. AMBIO: A Journal of the Human Environment, 37(4), 234-240.

Snedaker, S. (1984). The mangroves of Asia and Oceania: Status and research planning. Proceedings of the Asian Mangrove Symposium. 5-15.

Thompson, B., Clubbe, C., Primavera, J., Curnick, D., \& Koldewey, H. (2014). Locally assessing the economic viability of blue carbon: A case study from PanayIsland, the Philippines. Ecosystem Services, 8, 128-140.

Tomlinson, P. (1986). The Botany of Mangroves. Cambridge University Press.

Walters, B. (2004). Local management of mangrove forests in the Philippines: Successful conservation or efficient resource exploitation. Human Ecology, 32 (2), 177-195. 